\title{
Physicochemical, Microbiological and Sensory Qualities of Milk Extract from Three Varieties of Tigernut during Storage
}

\author{
*Babatuyi, Catherine Y., Akinyede, Adedamola. I. and Enujiugha, Victor. N. \\ Department of Food Science and Technology, Federal University of Technology, P. M. B. 704, Akure, Ondo \\ State, Nigeria. \\ *Email of the corresponding author: cybabatuyi@futa.edu.ng
}

\begin{abstract}
Tigernut milk extracted from three varieties in different locations were investigated for physicochemical, microbiological and sensory qualities during storage at ambient temperature $\left(27 \pm 2^{\circ} \mathrm{C}\right)$. Samples were taken daily to determine the total viable count, $\mathrm{pH}$, total titratable acidity, vitamin $\mathrm{C}$, viscosity, reducing sugar and sensory attributes. The microbial population and load were increased over a period of time with fresh yellow tiger nut milk sample $(X Y)$ having the highest total viable mesophilic bacterial load $\left(1.0 \times 10^{3}\right.$ to $\left.7.0 \times 10^{4} \mathrm{cfu} / \mathrm{ml}\right)$, followed by Dry small brown tigernut milk sample (ZZ) with highest population of lactic acid bacteria $\left(6.0 \times 10^{3}\right.$ to $4.5 \times 10^{4}$ $\mathrm{cfu} / \mathrm{ml})$ and the lowest fungal count $\left(2.0 \times 10^{3}\right.$ to $\left.1.1 \times 10^{4} \mathrm{sfu} / \mathrm{ml}\right)$, while Dry big brown tiger nut milk sample (YZ) had the highest $\left(2.70 \times 10^{4} \mathrm{sfu} / \mathrm{g}\right)$ fungal count. Five species of microorganisms were identified. There was drop in the $\mathrm{pH}$ values from 4.7 to 3.6 with the increase in the percentage of total titratable acidity (TTA) from $0.49 \%$ to $1.06 \%$ over time in all the milk samples. Viscosity at 5\% of YZ milk sample was steady (1.0 Cp), while others decreased from 2.0 to $1.0 \mathrm{Cp}$. Likewise, the percentage sugar brix level of the milk samples decreased from $5.99 \%$ to $2.49 \%$ and vitamin $\mathrm{C}$ from $30.21 \mathrm{mg} / 100 \mathrm{~mL}$ to $20.14 \mathrm{mg} / 100 \mathrm{ml}$. The sensory qualities of milk sample ZZ had the best overall acceptability while the milk sample $\mathrm{YZ}$ was least accepted.
\end{abstract}

Keyword: Tigernut milk, Storage, Physicochemical properties, Sensory evaluation, Microbial load.

DOI: $10.7176 / F S Q M / 84-06$

\section{Introduction}

Tigernut tuber (Cyperus esculentus Lativum) is cultivated for both human and livestock consumption. It can be eaten raw, baked, roasted or processed into energetic drink for both young and old especially people who cannot take gluten, cow milk and its derivatives due to non-allergic effect (Galindo-Bonilla et al. 2002). It is classified as an underutilized crop despite its numerous health benefits which includes cardiac preventive, liver tonic, heart stimulant and ability to heal mouth and gum ulcers (Sánchez-Zapata et al. 2012). It also enhances normal menstruation in women, use in Ayurvedic medicines and has a powerful aphrodisiac as well as for breast lumps and cancer (Sánchez-Zapata et al. 2012; Allouh et al., 2015). Studies have shown that variations in physicochemical and sensory qualities among tigernut cultivars depend on soil type, geographical location, treatment given and the harvest period (Asante et al., 2014; Codina-Torrella et al., 2015; Kizzie-Hayford, 2017). Freshly processed tigernut milk has a pH of 6.2-7.0 (Corrales et al., 2012). However, studies on the storage quality as influenced by the microbial, physicochemical and sensory qualities of tigernut milk at ambient temperature need to be investigated. Therefore this study was carried out to assess the effect of microbiological, physicochemical and sensory attributes of milk produced from three cultivars of tigernut tuber and stored at ambient temperature $\left(27 \pm 2^{\circ} \mathrm{C}\right)$ storage.

\section{Materials and Methods \\ 2.1 Collection of materials}

Tigernut cultivar tubers (yellow fresh nuts) were obtained from Akure market, Ondo State while, big brown dry and small brown dry were obtained from Abuja market, Federal Capital Territory (F.C.T), Abuja, Nigeria respectively.

\subsection{Chemicals and reagents}

All chemicals and reagents used were of analytical grade. Deionised water was used for the preparation of all solutions. 


\subsection{Processing of tigernut milk}

The tiger nut tuber was processed into milk using the method described by Udeozor (2012). Two hundred grams $(200 \mathrm{~g})$ each of varieties of tiger nut roots were washed, soaked in $500 \mathrm{~mL}$ of sterilized water for eight (8) hours, after which they were wet milled, sieved using Muslin cloth to obtain milk in a sterilized covered container and pasteurized at $72{ }^{\circ} \mathrm{C}$ for $5 \mathrm{~s}$ and stored at ambient temperature $(27 \pm 2){ }^{\circ} \mathrm{C}$ prior to analysis.

\section{$2.4 \quad$ Storage}

The tigernut milk samples were kept at ambient temperature $\left(27 \pm 2{ }^{\circ} \mathrm{C}\right)$ for 4 days to check the effect of storage.

\subsection{Microbiological analysis}

Diluent (saline solution) and media [Nutrient Agar (NA), deMan Rogosa Sharpe Agar (MRS) and Potato Dextrose Agar (PDA)] were prepared according to manufacturer's specification for isolation. Isolated microorganisms were characterized and identified by microbiological standard method according to Barnett and Hunter, (1972); Cowan, (2002) and Fawole and Oso, (2007).

\subsection{Physicochemical analysis}

The following physicochemical analysis were carried out in accordance to the standard scientific method described below

Determination of $\mathrm{pH}$ : The $\mathrm{pH}$ was determined according to the method of A.O.A.C. (2012).

Determination of Total Titratable Acidity (TTA): The percent titratable acidity was determined as described by A.O.A.C. (2012). The mean of TTA was obtained from triplicate determination and calculated as follows:

$$
\operatorname{TTA}(\%)=\frac{\text { Average titre value } \times 0.1 M \times 0.009008}{\text { Weight of sample }} \times 100
$$

Determination of Viscosity: The viscosity of varieties of tigernut milk was determined using the method of Singh and Kaur (2004). The tiger nut milk was prepared in 5\% (w/v) suspension. They were heated in boiling water at $90{ }^{\circ} \mathrm{C}$ for $30 \mathrm{~min}$ in a temperature-controlled water bath (Labon model WBN 007) with continuous stirring. The paste was transferred to a rotary viscometer (Rion Viscotester VT- 04E Co, Ltd Tokyo Japan), using the rotor No 1. It was measured at temperature range of $30^{\circ} \mathrm{C}$ to $90{ }^{\circ} \mathrm{C}$ and expressed in Centi Pascal (Cp).

Determination of Total Sugar Level: The total sugar level ( ${ }^{\circ}$ Brix) of each tigernut milk sample was carried out using refractometric method (Soluble solids) using hand Refractometer (Atago Brix 0-32\% Model TM 1600, Gibertini, Italy). The Refractometer was cleaned and standardized using distilled water at $20^{\circ} \mathrm{C}$ to 1.333 Refractive Index. Small drop of tigernut milk sample was put into the Refractometer to determine the refractive index of the milk at $20^{\circ} \mathrm{C}$.

Determination of Vitamin C: Vitamin C determination was done with little modification according to the method described by Awonorin and Udeozor (2014). Stock ascorbic acid solution was prepared using $0.1 \%$ solution of ascorbic acid in $0.4 \%$ oxalic acid solution. Working Standards (W.S.) 5, 10, 15, 20 and $25 \mathrm{ml}$ of the stock ascorbic acid solution was withdrawn and made up each to $500 \mathrm{ml}$ with $0.4 \%$ oxalic acid solution to de-hydroascorbic acid in an acid medium with a blue dye of 2.6-dichloroindophenol. These solutions numbered 1 to 5 contain 1, 2, 3, 4 and $5 \mathrm{mg}$ ascorbic acid per $100 \mathrm{ml}$ respectively. To four ascorbictiometer tubes add the following:

(a) D.W - $10 \mathrm{ml}$ water

(b) No $1-1 \mathrm{ml} 0.4 \%$ oxalic acid

(c) $\mathrm{S}-1 \mathrm{ml} \mathrm{WS} \mathrm{No.} 1+9 \mathrm{ml}$ water

(d) No 2-1 ml WS No 1 .

The absorptiometric was adjusted to zero using water (D.W.) and a green filter (approx. $520 \mathrm{ml}$. To tube no 1,9ml standard dye solution $(0.0012 \%)$ was added, mixed and recorded to reading $\left(\mathrm{L}_{1}\right)$ exactly 15 seconds. After adding, the dye was used to adjust the instrument to zero with tube in the absorption meter. To tube No. 2, 9 ml dye was added, mixed and read after 15 seconds. $\left(\mathrm{L}_{2}\right) . \mathrm{L}_{1}$ and $\mathrm{L}_{2}$ were recorded for each working standard and the standard curve was constructed with concentrations of ascorbic acid $(\mathrm{mg} / 100 \mathrm{ml})$ as abscissa and $\mathrm{L}_{1}$ and $\mathrm{L}_{2}$ for each working standard as ordinates. $50 \mathrm{~g}$ of the food sample was macerated for $3 \mathrm{mins}$ in a blender with $350 \mathrm{ml}$ of $0.4 \%$ oxalic acid solution and filtered and L1 was obtained as described above. $1 \mathrm{~mL}$ filtrated $+9 \mathrm{ml}$ water was added to the tubes and adjusted the instrument to zero. Then to tube Number 2 , was added $1 \mathrm{~mL}$ filtrated $+9 \mathrm{ml}$ dye and 
recorded $\mathrm{L}_{2}$ after 15 seconds. $\mathrm{L}_{1}$ and $\mathrm{L}_{2}$ were calculated and the concentration of ascorbic acid was obtained from the standard curve.

\subsection{Sensory evaluation}

The test samples were carried out with the use of questionnaire as described by Larmond (1982). Panelists were drawn from the university community and the samples were coded and presented to panelists to score for sensory qualities namely aroma (odour), taste, appearance/colour and overall acceptability using 9-point Hedonic scale.

\subsection{Statistical analysis}

Data obtained from the analysis were subjected to analysis of variance; (ANOVA) and the means were separated using Duncan's Multiple Range Tests using Statistical Package for Social Science (SPSS) version 21.0.

\section{Results and Discussion}

\subsection{Microbial status and effect of storage on the microbiological quality of tigernut milk}

A total of 12 different genera of microorganisms were isolated from the extract of the milk samples which includes: Bacillus cereus, Bacillus subtilis, Bacillus licheniformis, Staphylococcus aureus, Leuconostoc mesenteroides, Saccharomyces cerevisiae, Saccharomyces exiguus, Penicillium chrysogenum, Pediococcus cerevisiae, Candida pseudotropicalis, Neurospora crassa, and Articulospora inflate. The populations of the microorganisms (total viable bacteria, lactic acid bacteria and fungi) were found on $3^{\text {rd }}$ day (Day 2) and increased to the end of the storage period (Fig. 1a-c). Sample XY ranged from $1.0 \times 10^{3} \mathrm{cfu} / \mathrm{g}$ to $7.0 \times 10^{4} \mathrm{cfu} / \mathrm{g}$. Sample YZ had $1.0 \times 10^{3} \mathrm{cfu} / \mathrm{g}$ to $4.0 \times 10^{4} \mathrm{cfu} / \mathrm{g}$ and sample $\mathrm{ZZ}$ had $1.0 \times 10^{3} \mathrm{cfu} / \mathrm{g}$ to $4.5 \times 10^{4} \mathrm{cfu} / \mathrm{g}$ respectively. A steady increased in all samples as regards microbial load was observed during storage period. In all samples on Day 0 and Day 1 , no microbial growth was observed. This could be as a result of heat treatment (pasteurization) after milk production which was in agreement with Onovo and Ogaraku (2007) that heat treatment, proper storage and heat processing has the ability to inhibit microbial growth enough to kill any form of microorganisms. The levels of microbes present over the ambient storage period were below the limit of acceptance which is $2.0 \times 10^{5} \mathrm{cfu} / \mathrm{ml}$ for dairy milk by Codex Alimentations Commission (FAO/WHO, 2002).

\subsection{Effects of storage on $\mathrm{pH}$ and TTA of tigernut milk}

Storage of the extracted cultivars of tigernut milk had a significant $(\mathrm{p}<0.05)$ effect on the $\mathrm{pH}$ and total titratable acidity (TTA). The milk sample $\mathrm{ZZ}$ had the least $\mathrm{pH}$ of 3.6 and highest total titratable acidity of $1.06 \%$. As the days of storage at $\left(27 \pm 2^{\circ} \mathrm{C}\right)$ increased from day 2 , fermentation set in which reduce the $\mathrm{pH}$ of the milk samples and their TTA increased due to increase in storage period (Fig 2a-b). A decrease in $\mathrm{pH}$ from 4.7 to 3.6 and an increase in TTA from 0.36 to $1.06 \%$ was observed which was in agreement with the report of Ogbonna et al. (2013). The reduction in the $\mathrm{pH}$ could have effect on the sensory qualities as it poses reduction in microbial growth due to the accumulation of organic acids mainly lactic and acetic acids produced by lactic acid bacteria which constituted the dominant specific microbiota to inhibit spoilage and pathogenic microorganisms that may cause gastrointestinal problems (Komolafe and Arawande, 2010). In this study, due to uncontrolled temperature and increased days of storage, proliferation of microbial succession had rejection on the sensory qualities carried out on the milk samples.

\subsection{Effects of storage on viscosity and sugar level ( ${ }^{\circ}$ Brix) of tigernut milk}

The viscosity of the milk samples is shown on Fig. 2c. Sample YZ showed consistent (uniformity) in the viscosity throughout the period of storage $(0.10 \mathrm{Cp})$ and did not give a good mouth feel. The acceptability of liquid or semisolid foods depends on the viscosity or consistency index of the product in magnitude of internal fiction of the fluid with effect on the taste and mouth feel. The reduction ranged between milk samples XY (0.20 to $0.10 \mathrm{Cp})$ and $\mathrm{ZZ}(0.15$ to $0.10 \mathrm{Cp})$. The reduction in the viscosity may be due to synaeresis (separation of liquid from a gel) as the days of storage increased (Ogbonna et al. 2013; Okyere and Odamtten, 2014). 

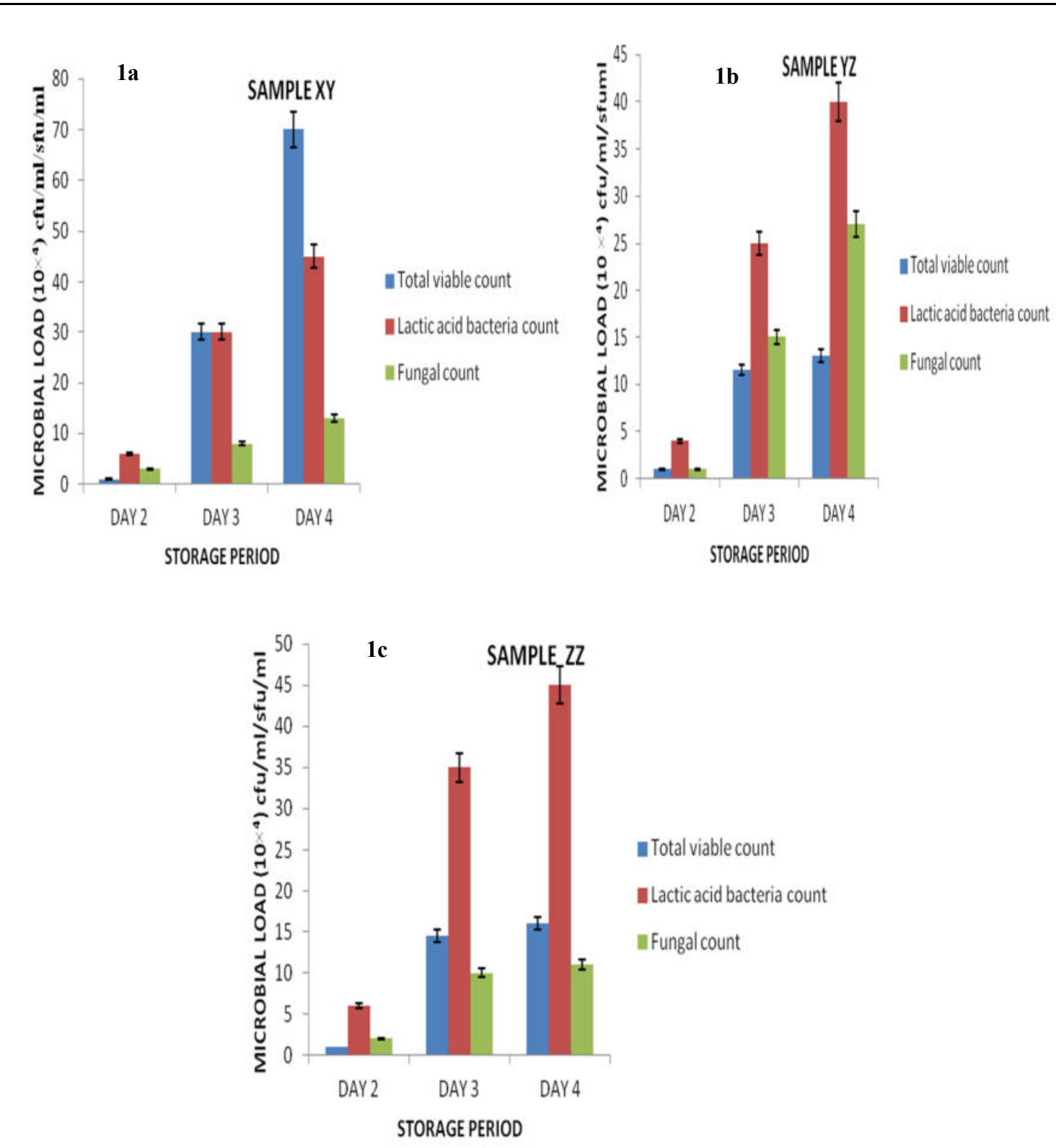

Figure 1(a-c): The microbial load during storage period of tigernut milk 

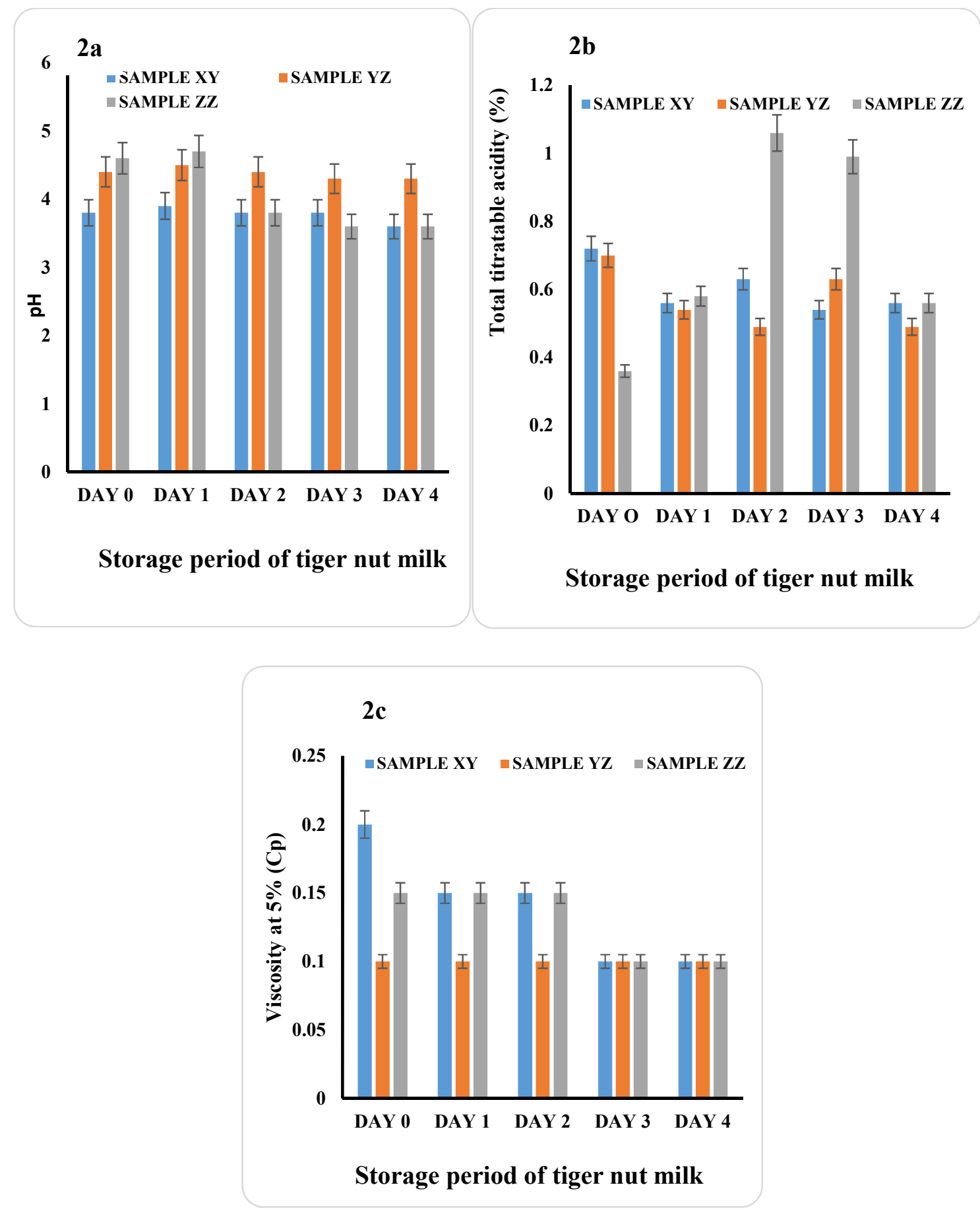

Figure 2(a-c): Effects of storage on pH, TTA and viscosity of tigernut milk 
Thereby, the tigernut milk might undergone rapid creaming, partly because of the considerable proportion of droplets of fats, which is non-polar and has a lower density than the continuous phase (Ekeanyanwu and Ononogbu, 2010; Codina-Torrella et al., 2016).

There was reduction in the percentage (\%) sugar brix level of all milk samples as the days of storage increased. The milk sample XY had least (2.49 \pm 0.01$)$ sugar brix level, while milk sample YZ had the highest $(5.99 \pm 0.01$ value and did not give a good taste. This could be attributed to the soil vegetation as the soil type defines the sugar level and a similar difference was reported in the works of Codina-Torrella et al. (2015). The reduction in the sugar level as the days of storage increase could be due to metabolic activities of microorganisms, using sugar as a source of energy, thereby causing proliferation of more microorganisms as they are not controlled. This milk without added sugar may be recommended for diabetes due to its carbohydrate content which is a base of sucrose and starch (without glucose) and it has arginine which liberates the hormone insulin (Gambo and Da'u, 2014).

\subsection{Effects of storage on vitamin $C$ content of tigernut milk}

Vitamin $\mathrm{C}$ is essential for body growth and development, and it is heat labile as it oxidizes easily, thus, it is used as an index of quality (Onyeka, 2008). A significant reduction $(\mathrm{p}<0.05)$ was observed in the vitamin $\mathrm{C}$ level of the milk samples. The reduction ranged from $30.21 \pm 0.59 \mathrm{mg} / 100 \mathrm{~mL}$ to $20.14 \pm 0.13 \mathrm{mg} / 100 \mathrm{~mL}$. Pasteurization $\left(72{ }^{\circ} \mathrm{C}\right.$ for $5 \mathrm{sec}$ ) carried out on the milk samples was done at lower temperature thereby preventing heat liable nutrients from being lost when freshly processed. This explains why vitamin $\mathrm{C}$ was present in small amount but later reduced as storage day's increase as a result of auto-oxidation and light effect which cause leaching of heat liable nutrients into the substrate which was in agreement with the work of Shukla et al. (2017).

Table 1: Effects of Storage on Vitamin C Content of Milk Tigernut

\begin{tabular}{cccccc}
\hline $\begin{array}{c}\text { Vitamin C } \\
(\mathrm{mg} / 100 \mathrm{~mL})\end{array}$ & Day 0 & Day 1 & Dtorage Days & Day 2 & Day 3 \\
\hline XY & $27.83 \pm 0.15^{\mathrm{b}}$ & $27.85 \pm 0.12^{\mathrm{b}}$ & $25.50 \pm 0.43^{\mathrm{b}}$ & $21.15 \pm 0.64^{\mathrm{c}}$ & $20.14 \pm 0.13^{\mathrm{b}}$ \\
YZ & $30.21 \pm 0.59^{\mathrm{a}}$ & $30.21 \pm 0.59^{\mathrm{a}}$ & $29.15 \pm 0.74^{\mathrm{a}}$ & $27.18 \pm 0.42^{\mathrm{a}}$ & $23.64 \pm 0.47^{\mathrm{a}}$ \\
ZZ & $27.82 \pm 0.15^{\mathrm{b}}$ & $27.83 \pm 0.15^{\mathrm{b}}$ & $26.26 \pm 0.35^{\mathrm{b}}$ & $23.39 \pm 0.34^{\mathrm{b}}$ & $20.77 \pm 0.88^{\mathrm{b}}$ \\
\hline
\end{tabular}

Mean \pm Standard deviation. Values with different superscript in the same row are significantly different $(P<0.05)$. Key XY: Fresh yellow tiger nut milk; YZ: Dry big brown tiger nut milk and ZZ: Dry small brown tiger milk.

Table 2: Effects of Storage on Sugar Content of Milk Tigernut

\section{Brix Refractometer}

$(\%)$

$\mathrm{XY}$

YZ

ZZ

Storage Days

\begin{tabular}{cccrr} 
Day 0 & Day 1 & Day 2 & Day 3 & Day 4 \\
$3.49 \pm 0.01^{\mathrm{c}}$ & $3.49 \pm 0.01^{\mathrm{c}}$ & $2.99 \pm 0.01^{\mathrm{b}}$ & $2.50 \pm 0.01^{\mathrm{c}}$ & $2.49 \pm 0.01^{\mathrm{c}}$ \\
$5.99 \pm 0.01^{\mathrm{a}}$ & $5.99 \pm 0.01^{\mathrm{a}}$ & $5.20 \pm 0.01^{\mathrm{a}}$ & $4.89 \pm 0.01^{\mathrm{a}}$ & $3.99 \pm 0.01^{\mathrm{a}}$ \\
$5.01 \pm 0.01^{\mathrm{b}}$ & $4.99 \pm 0.01^{\mathrm{b}}$ & $4.49 \pm 0.01^{\mathrm{b}}$ & $3.99 \pm 0.01^{\mathrm{b}}$ & $3.49 \pm 0.01^{\mathrm{b}}$ \\
\hline
\end{tabular}

Mean \pm Standard deviation. Values with different superscript in the same row are significantly different $(\mathrm{P}<0.05)$. Key XY: Fresh yellow tiger nut milk; YZ: Dry big brown tiger nut milk and ZZ: Dry small brown tiger milk

\subsection{Effects of storage on sensory properities of tigernut milk}

The extraction of varieties of tigernut milk had a significant difference $(p<0.05)$ effect on the sensory evaluation. Sample ZZ was rated the best in all the qualities (taste, colour, aroma and mouth feel) scored irrespective of the storage period. However, the taste of tiger nut milk depends on the sugar content (soil type) to give a very characteristic aroma (flavour) and it is known to promote good mouth feel. The mouth feel of sample $\mathrm{ZZ}$ was rated the best and this is considerable the same with the report of Onweluzo and Nwakalor, (2009), unlike other phytomilk, tigernut milk has no beany flavour and throat catching sensations (Awonorin and Udeozor, 2014), but as days of storage increased, microbial influence affected the sensory qualities having lower sensory scores for sourness, texture, appearance and overall acceptance in all the milk samples as reported by Ocheme et al. (2011). 
Table 2: Effects of Storage on Sensory Attributes of Milk Tigernut

\begin{tabular}{|c|c|c|c|c|c|}
\hline Samples & Appearance & Taste & Aroma & Mouth feel & Overall acceptability \\
\hline \multicolumn{6}{|c|}{ Day 0} \\
\hline $\mathrm{XY}$ & $6.67 \pm 0.07^{b}$ & $6.67 \pm 0.07^{\mathrm{b}}$ & $7.67 \pm 0.02^{b}$ & $7.67 \pm 0.01^{\mathrm{a}}$ & $7.67 \pm 0.05^{\mathrm{b}}$ \\
\hline YZ & $5.67 \pm 0.01^{\mathrm{c}}$ & $6.67 \pm 0.01^{\mathrm{b}}$ & $6.67 \pm 0.04^{\mathrm{c}}$ & $6.67 \pm 0.05^{b}$ & $6.67 \pm 0.03^{c}$ \\
\hline $\mathrm{ZZ}$ & $7.67 \pm 0.03^{\mathrm{a}}$ & $8.67 \pm 0.03^{\mathrm{a}}$ & $8.67 \pm 0.01^{\mathrm{a}}$ & $7.67 \pm 0.03^{\mathrm{a}}$ & $8.67 \pm 0.07^{\mathrm{a}}$ \\
\hline \multicolumn{6}{|c|}{ Day 1} \\
\hline$X Y$ & $6.67 \pm 0.01^{\mathrm{a}}$ & $5.67 \pm 0.01^{\mathrm{b}}$ & $7.67 \pm 0.02^{\mathrm{a}}$ & $7.67 \pm 0.01^{\mathrm{a}}$ & $6.67 \pm 0.09^{b}$ \\
\hline YZ & $5.67 \pm 0.03^{c}$ & $5.67 \pm 0.04^{\mathrm{b}}$ & $5.67 \pm 0.05^{\mathrm{b}}$ & $5.67 \pm 0.03^{b}$ & $5.67 \pm 0.01^{\mathrm{c}}$ \\
\hline $\mathrm{ZZ}$ & $7.67 \pm 0.11^{\mathrm{a}}$ & $7.67 \pm 0.01^{\mathrm{a}}$ & $7.67 \pm 0.01^{\mathrm{a}}$ & $7.67 \pm 0.09^{\mathrm{a}}$ & $8.67 \pm 0.02^{\mathrm{a}}$ \\
\hline \multicolumn{6}{|c|}{ Day 2} \\
\hline$X Y$ & $4.67 \pm 0.06^{\mathrm{b}}$ & $4.67 \pm 0.05^{\mathrm{b}}$ & $5.67 \pm 0.05^{b}$ & $5.67 \pm 0.02^{b}$ & $6.67 \pm 05^{\mathrm{b}}$ \\
\hline YZ & $3.67 \pm 0.01^{\mathrm{c}}$ & $3.67 \pm 0.01^{\mathrm{c}}$ & $4.67 \pm 0.01^{\mathrm{c}}$ & $4.67 \pm 0.01^{\mathrm{c}}$ & $4.67 \pm 0.01^{\mathrm{c}}$ \\
\hline $\mathrm{ZZ}$ & $7.67 \pm 0.03^{\mathrm{a}}$ & $6.67 \pm 0.03^{\mathrm{a}}$ & $6.67 \pm 0.07^{\mathrm{a}}$ & $6.67 \pm 0.07^{\mathrm{a}}$ & $7.67 \pm 0.03^{\mathrm{a}}$ \\
\hline \multicolumn{6}{|c|}{ Day 3} \\
\hline $\mathrm{XY}$ & $4.67 \pm 0.06^{\mathrm{b}}$ & $3.67 \pm 0.05^{\mathrm{b}}$ & $4.67 \pm 0.03^{b}$ & $4.67 \pm 0.06^{b}$ & $4.67 \pm 0.02^{b}$ \\
\hline YZ & $3.67 \pm 0.01^{\mathrm{c}}$ & $2.67 \pm 0.01^{\mathrm{c}}$ & $2.67 \pm 0.01^{\mathrm{c}}$ & $3.67 \pm 0.01^{\mathrm{c}}$ & $3.67 \pm 0.01^{\mathrm{c}}$ \\
\hline $\mathrm{ZZ}$ & $6.67 \pm 0.04^{\mathrm{a}}$ & $5.67 \pm 0.08^{\mathrm{a}}$ & $5.67 \pm 0.02^{\mathrm{a}}$ & $5.67 \pm 0.04^{\mathrm{a}}$ & $6.67 \pm 0.01^{\mathrm{a}}$ \\
\hline \multicolumn{6}{|c|}{ Day 4} \\
\hline$X Y$ & $3.67 \pm 0.05^{b}$ & $2.67 \pm 0.05^{\mathrm{b}}$ & $3.67 \pm 0.05^{\mathrm{a}}$ & $4.67 \pm 0.03^{b}$ & $4.67 \pm 0.01^{\mathrm{b}}$ \\
\hline YZ & $2.67 \pm 0.02^{c}$ & $1.67 \pm 0.03^{c}$ & $1.67 \pm 0.01^{\mathrm{b}}$ & $3.67 \pm 0.01^{\mathrm{c}}$ & $3.67 \pm 0.03^{c}$ \\
\hline $\mathrm{ZZ}$ & $5.67 \pm 0.06^{\mathrm{a}}$ & $4.67 \pm 0.01^{\mathrm{a}}$ & $3.67 \pm 0.01^{\mathrm{a}}$ & $5.67 \pm 0.02^{\mathrm{a}}$ & $6.67 \pm 0.02^{\mathrm{a}}$ \\
\hline
\end{tabular}

Mean \pm Standard Deviation. Values with different superscript along the same row are significantly different $(\mathrm{P}<0.05)$.

Key XY: Fresh yellow tiger nut milk; YZ: Dry big brown tiger nut milk and ZZ: Dry small brown tiger milk

\section{Conclusion}

Physicochemical and sensory attributes of tigernut milk produced and stored at ambient temperature $\left(27 \pm 2{ }^{\circ} \mathrm{C}\right)$ reduced with increase in storage days. Also the microbial status of the samples affected the milk qualities as the milk ages; indicating that milk samples are susceptible to spoilage and pathogenic microorganisms which may cause food borne-diseases if consumed.

\section{Reference}

Allouh, M. Z., Daradka, H. M and Ghaida, J. H. A. (2015). Influence of Cyperus esculentus tubers (tiger nut) on male rat copulatory behaviour. BioMedical Central Complementary and Alternative Medicine, 15:851859.

AOAC. (2012). Association of Official Analytical Chemist. Official Methods of Analysis of the Analytical Chemist International, $18^{\text {th }}$ ed. Gathersburg, MD USA.

Asante, F. A., Oduro, I., Ellis, W. O and Saalia, F. K. (2014). Effect of planting period and site on the chemical composition and milk acceptability of tiger nut (Cyperus esculentus L.) tubers in Ghana. American Journal of Food and Nutrition, 2:49-54.

Awonorin, S. O and Udeozor, L. O. (2014). Chemical Properties of Tiger nut-Soy Milk Extract. IOSR Journal of Environmental Science, Toxicology and Food Technology (IOSR-JESTFT), 8(1): 87-98.

Barnett, H. L and Hunter, B. B. (1972). Illustrated Genera of Imperfect Fungi. Third Edition, Minnesota, Burgess Publishing Company, Minneapolis, 214.

Codina-Torrella, I., Guamis, B., Ferragut, V and Trujillo, A. J. (2016). Potential application of ultra-high pressure homogenization in the physicochemical stabilization of tiger nuts' milk beverage. Innovative Food Science and Emerging Technologies, 1-10 
Codina-Torrella, I., Guamis, B and Trujillo, A. J. (2015). Characterization and comparison of tiger nuts (Cyperus esculentus L.) from different geographical origin. Industrial Crops and Products, 65: 406-414.

Corrales, M., de Souza, P. M., Stahl, M. R and Fernández, A. (2012). Effects of the decontamination of a fresh tiger nuts' milk beverage (horchata) with short wave ultraviolet treatments (UV-C) on quality attributes. Innovative Food Science and Emerging Technologies, 13: 163-168.

Cowan, S. T. (2002). Manual for the identification of medical bacteria. Second Edition: Cambridge University Press, London, 71.

Ekeanyanwu, R. C and Ononogbu, C. I. (2010). Nutritive value of Nigerian tiger nut (Cyperus esculentus L.). Medwell Journals (Agriculture), 5: 297-302.

FAO/WHO, (2002). Milk and milk products. Joint FAO/WHO Food standards programme. CODEX Alimentarius Commission, 42.

Fawole, M. O and Oso, B. A. (2007). Laboratory Manual of Microbiology. $4^{\text {th }}$ ed. Spectrum Books Ltd, Ibadan, 11-24.

Galindo-Bonilla, P. A., Gomez Torrijos, E., Borja Segade, J., Feo-Brito, F and Lombardero Vega, M. (2002). Allergy to tiger nut. Allergy, 57: 1083-1084.

Gambo, A. and Da'u, A. (2014). Tiger nut (cyperus esculentus): composition, products, uses and health benefits A review. Bayero Journal of Pure and Applied Sciences, 7(1): 56- 61.

Kizzie-Hayford, N. (2017). Doctoral thesis submitted to the Technische Universität Dresden, Faculty of Mechanical Science and Engineering, 1-116.

Komolafe, E. A and Arawande, J. O. (2010). Evaluation of the quantity and quality of "Gari" produced from three cultivars of cassava. Journal of Research in National development, 8 (1): 45-55.

Larmond, E. (1982). Methods for Sensory Evaluation of Foods. Agricultural Publications, 1637. Ottawa Canada, 20-23, 32-37.

Ocheme, O. B., Ariahu, C. C., Ingbian, E. K and Igyor, M. A. (2011). A survey of the traditional methods of processing dakuwa (a cereal/legume based snack food) in Niger State, Nigeria. Nigerian Food Journal, 29(1): 103-112

Ogbonna A. C., Abuajah, C. I and Utuk, R. A. (2013). Tiger nut Milk: A Nutritious Under-Utilized Food Ingredient. Food Biology, 2 (2):14-17.

Okyere, A. A and Odamtten, G. T. (2014). Physicochemical, functional and sensory attributes of milk prepared from irradiated tiger nut (Cyperus esculentus L.) Journal of Radiation Research and Applied Sciences, 7(4): 583-588.

Onovo, J. C and Ogaraku, A. O. (2007). Studies on some Microorganisms Associated with exposed tiger nut (Cyperus esculentus L.) milk. Journal of Biological Sciences, 7(8): 1548-1550.

Onweluzo, J. C and Nwakalor, C. (2009). Development and evaluation of vegetable milk from Treculia Africana (Decne) seed. Park. Journal of Nutrition, 8: 233-238.

Onyeka, U. E. (2008). Food and Nutrition. 2nd ed. Characteristic Forum Publications. No. 21. Mbaise Road, Owerri, Nigeria, 157.

Sánchez-Zapata, E., Fernández-López, J and Angel Pérez-Alvarez, J. (2012). Tiger Nut (Cyperus esculentus) commercialization: health aspects, composition, properties, and food applications, Comprehensive Reviews in Food Science and Food Safety, 11(4): 366-377.

Shukla, P., Bajwa, U and Bhise, S. (2017). Effect of Storage on Quality Characteristics of Pasteurized Mango Based Milk Beverage. Int. J. Curr. Microbiol. App.Sci, 6(11): 3446-3456.

Singh, N and Kaur, L. (2004). Morphological thermal, rheological and retrogradation properties of potato starch fractions varying in granules size. Journal of Science of Food and Agriculture, 84: 12411252 .

Udeozor, L. O. (2012). Tiger nut-Soy Milk Drink: Preparation, Proximate Composition and Sensory Qualities. International Journal of Food and Nutrition Science, 11(4): 18-26. 